\title{
TRANSFORMATION OF THE HISTORICAL TERRITORY UNDER THE IMPACT OF THE URBAN LOAD. JELGAVA EXAMPLE
}

\author{
Aija ZIEMEL̦NIECE \\ Department of Landscape Architecture and Planning, \\ Latvia University of Agriculture \\ E-mail:aija@k-projekts.lv
}

Received 23 March 2016; accepted 10 October 2016

\begin{abstract}
One of the most important issues in Latvia after gaining independence, as in all post-socialism countries, is the assessment and further development of the economic potential and the related urban space structure. The socio-economic preconditions of planning of the urban construction environment and the architectural spatial transformation are associated with the building reconstruction and regeneration. Today, an integral part of the transformation of inhabited areas is also building renovation and injection of landscape elements in the mechanical structures of the development plans of the Soviet times. These measures ensure a harmonious balanced living space and corresponding living conditions for residents (Treija et al. 2010).

The transformation process of the image of the architecturally spatial environment of inhabited areas is dynamic in its nature. This process is affected by socio-economic and engineering opportunities, as well as the peculiarities of the artistically aesthetic perception of the corresponding period. The image of the urban space has a very strong spiritual aura, which arises a series of thoughts, associations, views and emotions (Ziemelniece 2010). The main task of the compositional image of the urban environment is to generate positive feelings in the population or in each traveler who visits the particular settlement. The Latvian historical localities cities, manor ensembles, farmstead groups - over the centuries have been created as grid structures, where the social and economic activities overlap, according to the settlement function, scale and reachability (Briņkis, Buka 2006).
\end{abstract}

Keywords: urban space, transformation, urbanism, cultural and historical heritage, architecturally compositional structure, visually aesthetic quality.

\section{Introduction}

The Latvian urban network, with its specific hierarchy of communication at various levels of settlements, has historically formed between the $17^{\text {th }}$ and $19^{\text {th }}$ centuries in the period of the Duchy of Courland and the Russian Governorate. The historical overlaying has brought up grid-type structural settlements, which are mutually related to branched transport networks (Fig.1). Under the effect of several century overlaying, Latvia's population gravity field points have led to emerging of several larger cities with a strong economic, cultural and migratory life. No doubt, it has been influenced by nature and its geomorphological conditions. The urban area of Jelgava is one of such gravity points. Assessing the study materials, it is possible to define the aim of the research, which includes a more detailed study of the context of the urban construction space of Jelgava and its cultural and historical heri- tage, considering the historic structure of the urban environment and its transformation processes (Schlau 1995; Grosmane 2010).

The main assignments of the study are related to:

- The searches of inter-connectedness between the historical building and the compositional structure of the natural site;

- The consideration of the impact of the anthropogenic load on the cultural and historical values;

- The assessment of the opportunities of planning areas, adjusting the landscape protection zones, which in many places are not defined in the municipal planning tasks.

The above mentioned net-type structure exists and develops on functionally expressed features, such as:

- Territorially local placement of industrial sites;

- The main and underlying transport network - like linking framework of the territorial occupancy grid; 
- The engineering infrastructure in the locality;

- The unifying natural environment with forests and the agricultural landscape, creating a site for recreation.

In order to purposefully improve the structure of the architectural planning of the cultural and historical heritage and to save it, it is necessary to classify the existing planning by the following parameters:

- The historical period of the formation of the locality;

- The context of the architecturally spatial heritage and the role in the development of the urban environment (Brinkisis, Buka 2008).

\section{Materials and methods}

On the basis of the two main indicators of the existing planning classification mentioned above, the architectural heritage of the historic cities of Latvia has been assessed. The inspection criteria and the methods used enable to split the historical localities into three classes:

Class A - localities, where the historically architectural planning significantly affects the whole structure of the urban construction, its spatial composition and the form of the architectural composition of the locality. They are localities based on the remained historical planning, high quality ensembles and their complexes with a clear perception and inter-connectivity, as well as a subordinate building which is architecturally valuable and appropriate to the scale of the ensembles.

Class B - localities where the historic planning has remained fragmented and the major ensembles have no significant role in the architectural form of the urban or rural locality. The close spatial inter-connectedness between the most important architectural monuments is partially lost, the harmonious relationship between the major objects of the ensemble and the subordinate building is disrupted.

Class C - inhabited localities in which the historical heritage (the planning structure, building ensembles and subordinate building mass) are visible only as individual elements, not inter-connected in the whole planning structure (Brinkis, Buka 2006).

The second method of inspection according to the assessment of the criteria of the cultural and historical heritage - the potency of the urban environment and the quality assessment. It is carried out by the expert group of the regional environmental planners, who by certain criteria assess the architectural quality of the urban space under the study. This method is usually based on 3 main assessment blocks:
1. The place and role of the city in the population system:

- The potencies of the service system and the field of gravitation;

- The cultural-historical and architectural-spatial heritage;

- Tourist attraction.

2. The role of the natural elements in the urban development process:

- The peculiarities of the terrain and its meaning in the creation of the urban space;

- Water tanks and their diversity;

- Forest, forest park and greening areas, green recreational opportunities.

3. The city's architecturally compositional quality:

- The expressiveness of the structure of the spatial planning;

- The panoramic and the silhouette's perceptability (Briņķis, Buka 2006).

\section{Results and discussions}

At the basis of the creation of the urban construction of Jelgava, there are 4 stages of development defined, which include approximately 150 years of history:

- The second half of the $19^{\text {th }}$ century until World War I - a rapid economic boom of the city, the building density and height gain, as well as the change from the wooden building to masonry buildings.

- The post-war years between the 20 s and 30 s of the $20^{\text {th }}$ century and the time of the agrarian land reform, which brings a more intensive tempo of the industrial and infrastructure development to the the city.

- The post-war years between the 50s and 90s of the $20^{\text {th }}$ century. The city is brought to life from the ruins from scratch, bringing in a building scale of an alien standard and awareness of the architectural-spatial structure.

- The start of the 21st century - modernist trends and the creation of an energy-efficient environment, searching accents of the regional identity in the urban planning.

Each of the above periods have a close link with the transformation processes of the urban construction space.

Upon considering the above inspection criteria used for splitting the historical settlements into segments, the city of Jelgava falls into Class C. So, in the today's view, the city's historical heritage (the building structure, building ensembles and their subordinate building mass) are visible only as individual elements, not inter-connected in the whole planning structure. 


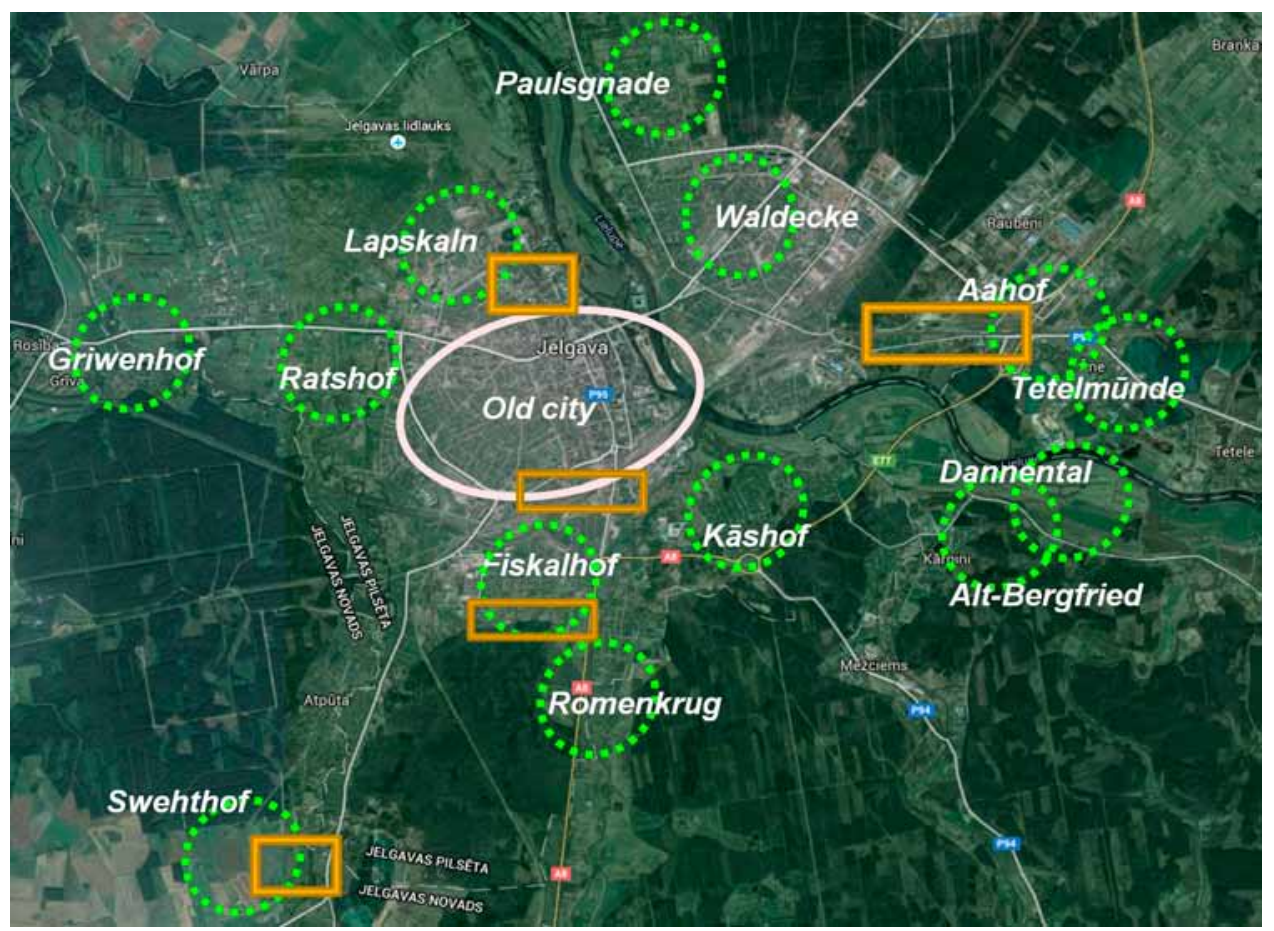

Fig. 1. Circumferentially, around the historical center of the city of Jelgava, 1-5 km away manor building ensembles were located. $19^{\text {th }}$ century

Source: author's scheme.

Having considered the above, the study addresses the peculiarities of the structure of the cultural and historical space that have formed in the course of the transformation processes of the urban environment in the city of Jelgava (Jelgavas teritorijas plānojums 1999).

With the development of the city, in the 50s of the $17^{\text {th }}$ century around it the city's rampart and the defensive moat filled with water are erected, strictly separating the city's part from the out-of-town rural area. In turn, by extending the city, the major changes in its territory date back to the start of the $19^{\text {th }}$ century, with demolition of the city's ramparts (Ziemelniece 2012).

Circumferentially, around the historical center of the city of Jelgava, $1-5 \mathrm{~km}$ away manor building ensembles were located. The structure of the manor placement was subordinated to the peculiarities of the natural site - the dense network of the rivers, forest areas and the fertility of the land. According to the geographical location, the basin of the left bank of the river Lielupe can be characterized by a dense network of rivers with vast flood plain areas in springs. In the urban area, the right bank of the river Lielupe has one tributary - the river Iecava with its woodland tributary - the river Misa, bringing massive waters and massive flooding in spring in the place where it flows into the river Lielupe. Consequently, extensive flood zones are focused around the historic urban building area, which has historically determined location of the building area.
Around Jelgava, at the basis of the geomorphological structure of both banks of the river Lielupe there are sandy soils, which are not fertile enough for the agricultural farming. In turn, the sandy base is advantageous in construction as it is characterized by higher basic load-bearing capacity. With the 20 s of the $20^{\text {th }}$ century, the building of the city developed on the left side of the river. Only with the 30 s of the $20^{\text {th }}$ century, an intensive building of the right bank began, providing extensive industrial areas. During this time, the opportunities for Jelgava to get additional area required for further development were open by the agrarian land reform in Latvia. It resulted in including the private manors and the so-called Crown Estates in the National Land Fund. For Jelgava, such extensive area was needed to favor the growth of the infrastructure of the cities of the new Latvian state (Tomašuns 2015).

The time of the Russian Governorate of the 60s of the 19th century brought new ripple in the historic building of the city as the construction of the railway began. Jelgava was formed as the largest rail line branching point in Kurzeme, where roads crossed to get to Liepāja, Ventspils, Berlin, Krustpils, Riga. The railroad was built through the cheapest lands and they were forest areas. Consequently, in the southwestern part of the city, the 3 main directions - Berlin, Liepāja, Tukums rail tracks split the historical continuous forest area into several parts. With the development of the railroad network, the 
city's growth was promoted. The huge rail track branching point attracted industrialists, thus contributing to the development of the industrial production in the city. Alongside with the railway network, countryside roads developed for drafters to get to the city. It was contributed by the dense radial arrangement of the manors around Jelgava. The building of the railroad network has created two broad rail track connection points, each of them on their river side. One of them on the right bank of the river Lielupe, in the $50 \mathrm{~s}$ of the $20^{\text {th }}$ century begins forming a wide industrial area around itself, associated with the production of building materials, the sugar refinery, agricultural machinery repair station, automotive production, oil base, locomotive repair depot, freight shunting area. In parallel, the industrialization develops infrastructure in line, associated with the years between $60 \mathrm{~s}$ and $70 \mathrm{~s}$ of the $20^{\text {th }}$ century. New multi-family residential buildings, school construction, hospitals, the culture house, sports halls, sports fields, university training corps and hostels, supermarkets, parking lots, road networks are developed in the neighborhood. The building load results in a reduction of green areas, creating only separate street plantings. This is well readable in the current outline of the city, compared to the historical materials. Until the 30 s of the $20^{\text {th }}$ century, the right bank of the river Lielupe is a the wide plain area with floodplain grasslands, which cover approximately a $500 \mathrm{~m}$ wide strip along the bank. In the plan of the city's development, the new Latvian government plans to develop the area of the right bank as an industrial one, which is in close inter-connectedness with the railway, road network and river transport. In the 80 s of the $19^{\text {th }}$ century, barges were intensively used, carrying bricks from clay kilns to the city. Therefore, the construction of a modern river cargo port was started in front of the historical palace. Thus, the industrial area of the right bank of the river with the fan-shape character of the compositional structure would be maintained with three modes of transport veining - the road, railway and river transport. In the post-war years, the post-socialism time brought in a new direction, creating the industrial load on both sides of the river and seamlessly focusing only along the railway. Even in the 60 s of the $19^{\text {th }}$ century, the positioning axis of the rail tracks in the east-west direction has also determined the basic character of the compositional structure. The rail track connection on the left bank of the river Lielupe develops a production area, associated with a warehouse base for a wide range of building materials, as well as the development of wood processing and concrete production in the postwar years (Fig. 2).

The development of industrial sites through transformation of manor lands.

Svēte Manor (1774, architect S. Jensen) from the beginning of the $19^{\text {th }}$ century to the 90 s of the $20^{\text {th }}$ century serves for military purposes. A new character of the building (horse stables, barrack buildings, roads, squares) is developing. From the $90 \mathrm{~s}$ of the $20^{\text {th }}$ century, the area of the manor has acquired the development of production and warehouse zones.

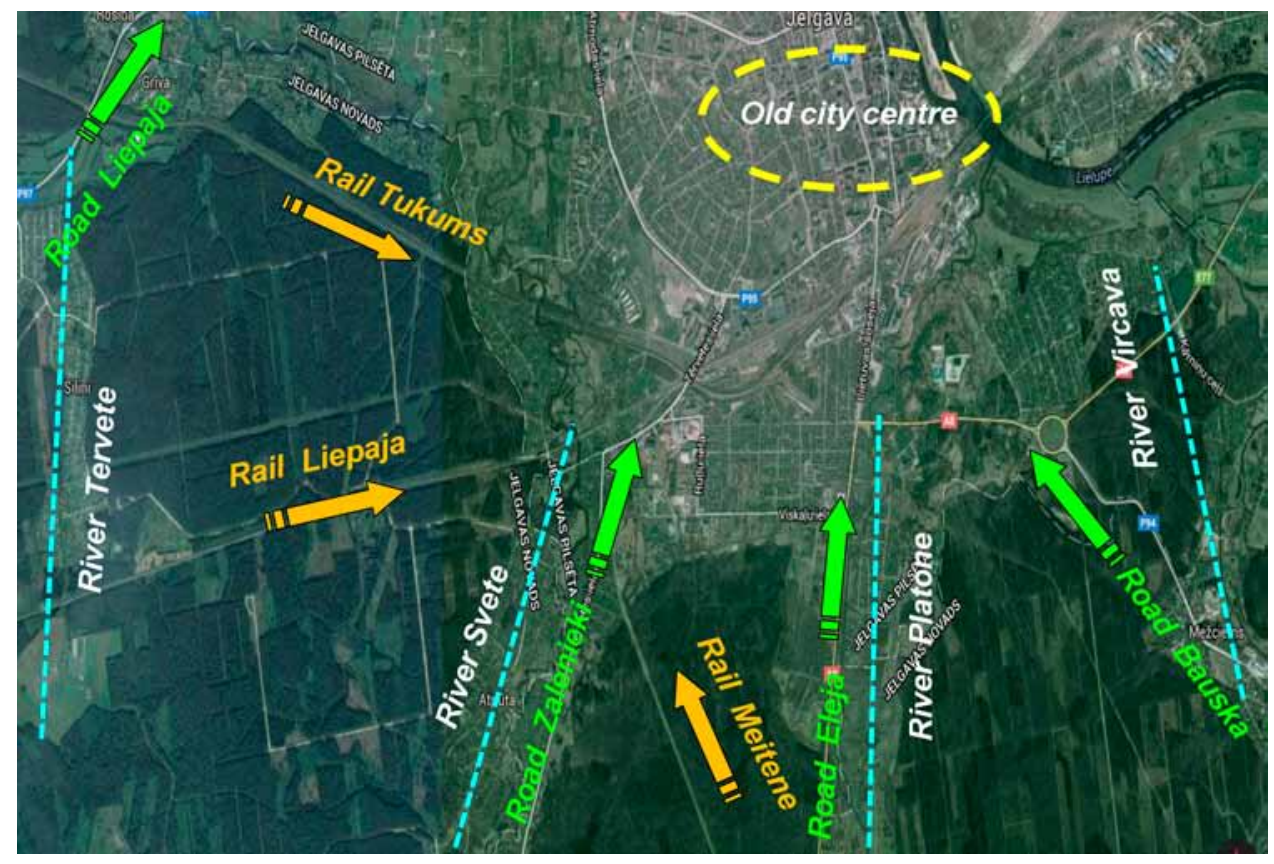

Fig. 2. Motorways, rail tracks and river networks, which in the in the 70 s of the $19^{\text {th }}$ century form the structure of the urban space

Source: author's scheme 


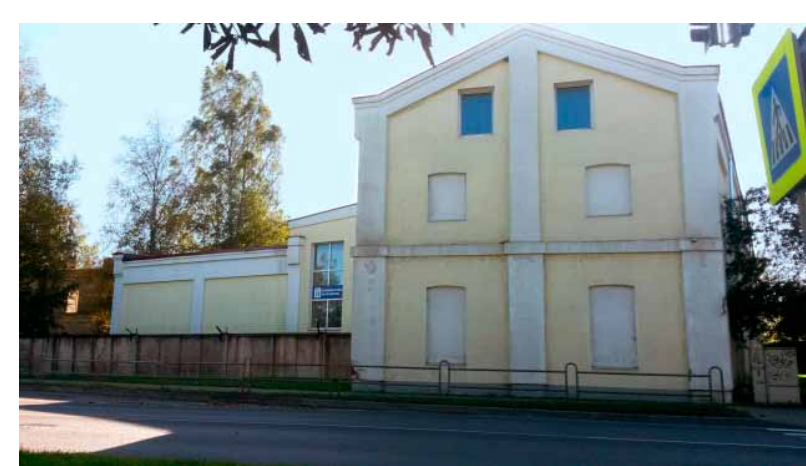

Fig. 3. Old M. Grebner wax cloth factory (end of the $19^{\text {th }}$ century) Source: author's photo, 2016

The Lapskalna Manor area - in the second half of the $19^{\text {th }}$ century, the building of the flax-spinning mill is evolving, which is easily reachable by boats along the river Lielupe. By up to the 90 s of the $20^{\text {th }}$ century, this factory develops impressively and forms a large building area. A little up the river Lielupe - sawmills and timber industry, a firewood place and windmills.

The Ane Manor (Aahof) area - the right bank of the river Lielupe, where at the end of the $19^{\text {th }}$ century with the formation of brick kilns, a brick plant is gradually developing. Its functions are not lost even today.

Behind the impressive career ponds and the construction volume of the production, the historic site is not apparent, except the old tree lane.

The development of industrial sites by the city's main roads that linked in Jelgava the second half of the $19^{\text {th }}$ century (Figs 3-6, 10).

The driveway from the west - the leather processing factory, Kramer key factory (Fig. 5). The south side road - from the end of the $19^{\text {th }}$ century - food processing companies, windmills, grain storage sites are developed. This function is preserved nowadays, through modernization of the production and building height. Closer to the city's center near the Platone river mouth to the river Lielupe - the development of

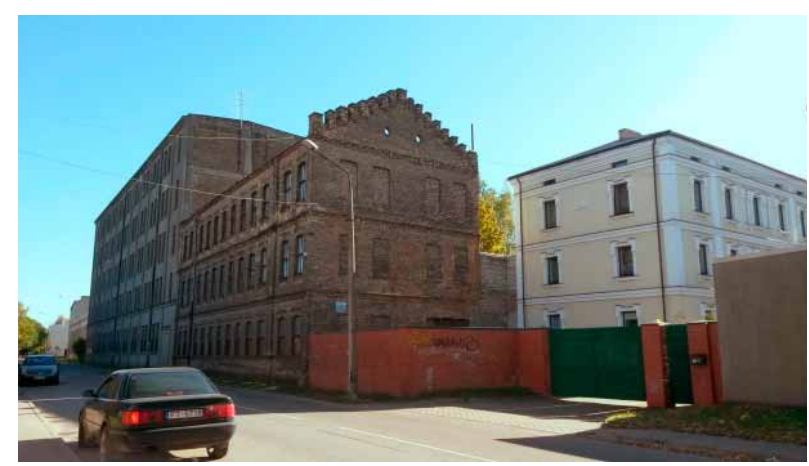

Fig. 5. Kramer key factory (80s of the $19^{\text {th }}$ century) Source: author's photo, 2016

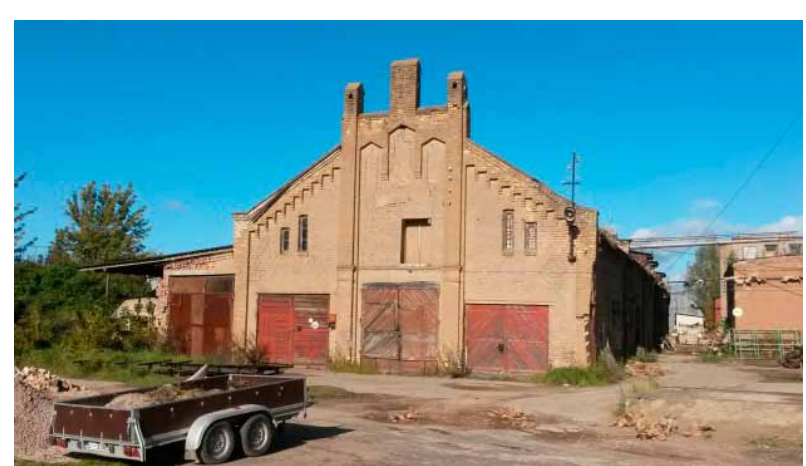

Fig. 4. Old leather factory (80s of the $19^{\text {th }}$ century) Souce: author's photo, 2016

the timber industry, the collection of the rafted timber and loading onto rail vehicles. At the roadside from the southwestern side - the M. Grebner wax cloth factory, workers' houses and a beautiful park (Fig. 3).

The development of the industrial zones was based on the waterway as the main artery, which historically kept up the ripple of the urban development. The land road and railway construction contributed to the growth of the city.

As one of the most historically broader production sites is the former M. Grebner wax cloth factory beside the rail tracks in this area. In the 90 s of the $19^{\text {th }}$ century, it was located in the out-of-town area that was rather away from the city center and distanced from the wooden residential building on Veidenbauma, Mātera, Zirgu, Stacijas streets. A broad meadow in the northern part of the area of the factory remained undeveloped until the 70 s of the $20^{\text {th }}$ century, when the construction of two schools and a multi-family residential building was started. The historical manufacturing created a new load of infrastructure that is particularly attributable to the increase of intensity of the countryside roads (Eleja and Tērvete land roads). The geographically convenient location between the former Gate of Anna and the Small Gate, and alongside the railway

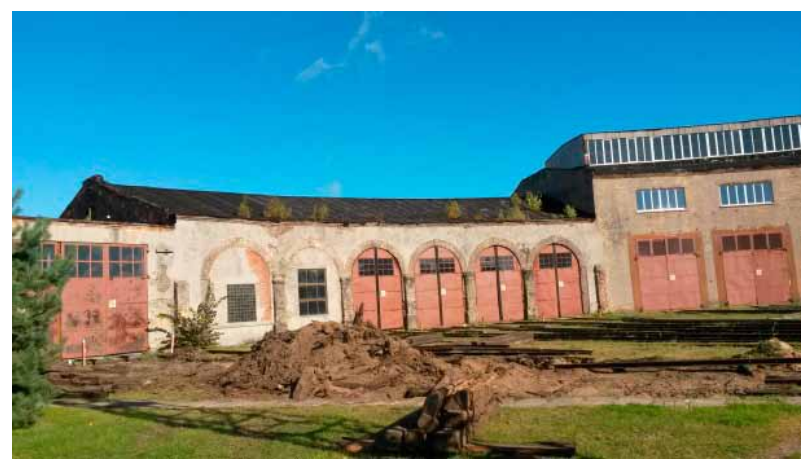

Fig. 6. Repair factory of the steam locomotive (90s of the $19^{\text {th }}$ century)

Source: author's photo, 2016 
contributed to the development of the surrounding area of the factory. In the start of the $20^{\text {th }}$ century, warehouse and production site areas began to concentrate along the rail track. The former Gate of Anna was $2 \mathrm{~km}$ away from the above mentioned historical production site, at which, in turn, a hospital, jail were built, which in the mid- $19^{\text {th }}$ century started to form a new infrastructure point. In the second half of the1 $9^{\text {th }}$ century, the new station building was added to it. These areas of the southern part of the city initiated a wave of a spatially expressed transformation process in the city. In turn, in the mid- $20^{\text {th }}$ century, with the expansion of both the jail and the station areas, part of the picturesque upstream of the river Lielupe and the flow of the river Platone into it were blocked. The transformation processes continue in this area, and the perspective plan of the city envisages removing part of the station's warehouse buildings to construct a new terminal area by the bridge extension, thus providing a reduction of the load of the road transport in the center of the city.

As a second important aspect, considering the impact of the industrial load of the period between the 50 s and 90 s of the $20^{\text {th }}$ century, the extinction of the cultural and historical environment can be mentioned, the existence of which is evidenced only by individual structural elements of the urban construction space.

The given study materials of the left bank of the river Lielupe show that the current urban construction space occupies the old manor building centers around which pastures and arable land are deployed. In the southern part of the city, where, for example, the Fiskāli manor building was located, a seed factory with processing workshops, but alongside it a electro-installation station was located. In turn, in the end of the $20^{\text {th }}$ century, removing the above mentioned production, a new mansion area has been developed, which is deployed up to the former Romas manor inn. The old inn building has kept its construction volume and proportion, and serves as a good landmark for the recognition of the cultural and historical environment. On the opposite bank of the river Platone, in the war years the building of Sieramuiža is lost and behind the river floodplain an allotment area is deployed, which gradually transforms into a mansion zone. In the eastern part, Dandāles and Vecsvirlaukas manor ensembles are located by the river Lielupe. Both manor complexes have been lost in the war years, but their historical landscape space has survived and it is recognizable. In the start of the 21st century, the above areas attract out-of-town scattered building for which a low-rise building character is set in the perspective. Among the above mentioned former manor areas, in the southern and eastern parts there is a forest area, which will be transformed into a forest park in the perspective.
The Industrial load has left an impact not only on the left bank of the river Lielupe, but also on the right bank of the river Lielupe. It is expressibly readable along the Krustpils railway. Parallel to the rail tracks, in the $60 \mathrm{~s}$ of the $20^{\text {th }}$ century the production load was additionally carried by the road transport in the direction of Iecava. This is especially true for the 70s of the $20^{\text {th }}$ century after the construction of the bypass. The brick plant and the huge clay mines have destroyed the landscape space of the Āne manor. A dense manor building has crept into the landscape of the outermost Telelminde manor.

In the city's development, the compositional axis of the northeastern part is determined by the Riga road that relatively to the current highway of Riga was approximately $150 \mathrm{~m}$ away. Its historic bottom is preserved even today. The Riga motorway, which is distanced from the rail tracks has not attracted industrial areas in the post-war years. An intensive development of the right bank of the river Lielupe began only in the 60 s of the $20^{\text {th }}$ century (İle 2011). The area is not affected by wars and the historical Valdeka palace has survived. In turn, with the increase of the building intensity in the period between $70 \mathrm{~s}$ and $80 \mathrm{~s}$ of the $20^{\text {th }}$ century, the forest array has receded, giving its place to 5 -story and 9 -story building. In the northern part along the right bank of the river Lielupe, in order to protect the area from the flood, in the $30 \mathrm{~s}$ of the $20^{\text {th }}$ century the road in the direction of Kalnciems with a ditch system is built as a dam. Considering the current development of the city's infrastructure, the construction of the North Bridge is planned (Fig. 7).

The third industrial zone in the city is readable in its northern part, on the left bank of the river Lielupe. It was formed in the second half of the $19^{\text {th }}$ century by constructing a flax spinning mill on the bank of the river Driksa, so easily ensuring both the raw materials and transport of the finished products by river transport. During the reconstruction of the flax spinning mill in the 70 s of the $20^{\text {th }}$ century, the building height of the buildings was increased. In the 80 s of the 20 th century, the huge building volumes were hidden behind the wooden building of Uzvaras street. However, the wooden heritage is lost as a result of an inept privatization, and it is currently being dramatically readable beside the former Villa Medem (Fig. 9). The disproportion of the construction volume of the flax spinning mill and the contrast of the architectural appearance are well readable as well (Fig. 8).

As the fourth industrial load zone, the southwestern part of the city is to be mentioned, where an intensive standard high-rise residential and industrial building was formed along the Tèrvete road. As a culmination, 


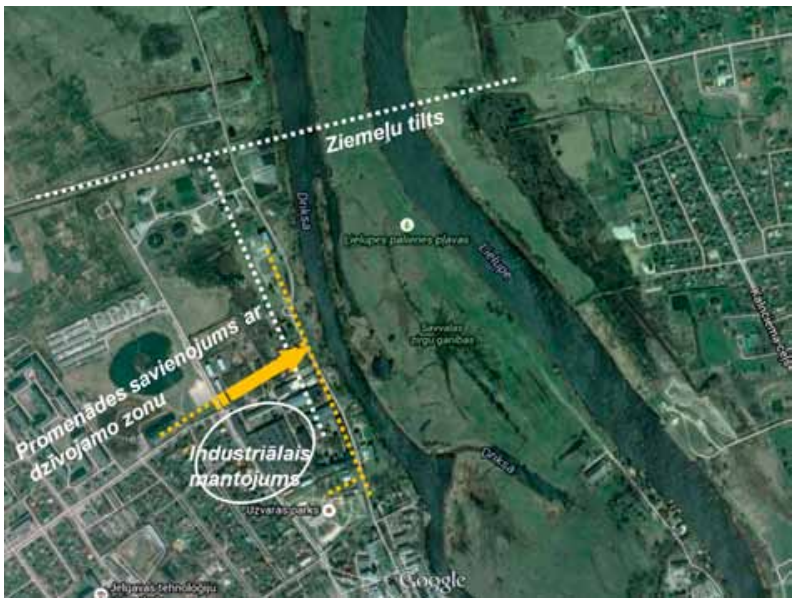

Fig. 7. The industrial zone at the Northern Gate

Source: author's scheme, 2015

the production area of the construction, formed in the period between the $80 \mathrm{~s}$ and $90 \mathrm{~s}$ of the $20^{\text {th }}$ century, is to be mentioned in the landscaped space of the Svète palace, where the transformation processes are brightly readable. The genesis of the cultural and historical area of the Svēte palace is analyzed in detail, which is based on 4 key aspects:

- with the rapid growth of the city in the second half of the $19^{\text {th }}$ century, its tempo was felt $5 \mathrm{~km}$ away in the placement of the Svete palace ensemble at the Tērvete road of an intense significance, where the load resulted in reducing the role of the cultural and historical space. So, it was a new move through the cultural and historical building, so changing its structural composition;

- as another important factor in the changes of the structure of the urban building is the peculiarities of the natural site. This is attributable to the river Svēte and its sprawling flood areas, flooding the historic road to the city;

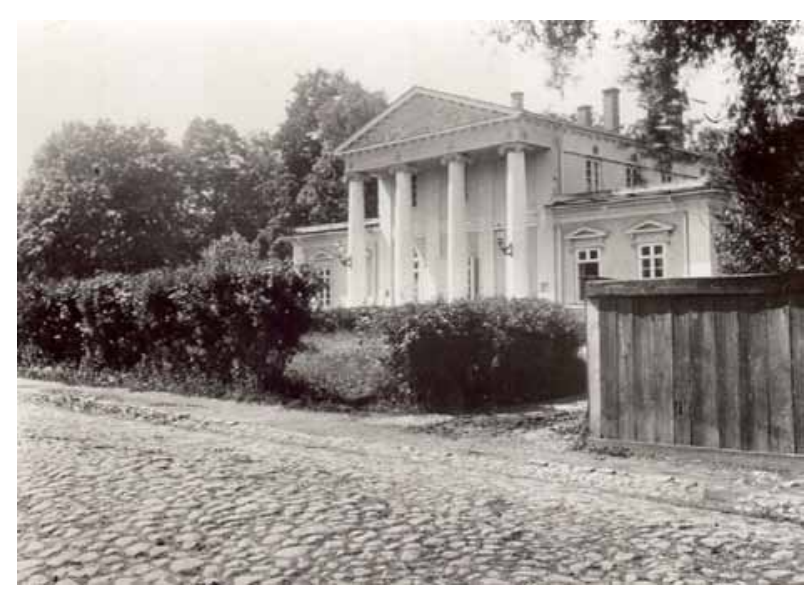

Fig. 9. Villa Medem, the 90 s of the $19^{\text {th }}$ century Source: a photo of History Museum of Jelgava

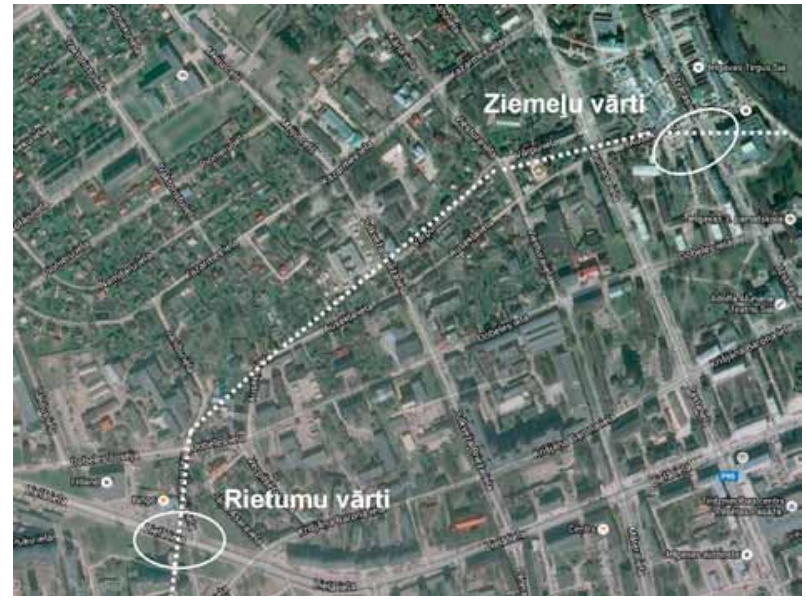

Fig. 8. The canvas of the historical sites of manors is readable in the contemporary urban structure

Source: author's scheme, 2015

- the loss of the cultural and historical significance of the ensemble of the Svète palace is much due to the nearness of the urban environment of Jelgava. The palace's spectacular construction volume contributed to its adjustment to military needs in the time of the Russian Governorate. The quickly and easily reachable city center and the deployment of the troops in the Svete palace, contributed to the rebuilding of the ensemble;

- the period between the 60 s and 80 s of the $20^{\text {th }}$ century and the errors of the compositional structure of the post-socialism time. Here you trace the loss of the historical silhouettes, culmination points and the lines of sight behind the new construction volumes, understanding... From the historic engraving of the Mikelte, it is evident that the landscape of the Svète palace is the most expressive in the distant lines of the sight. Unfortunately, due to the extension of the urban construction areas, the unique values are lost.

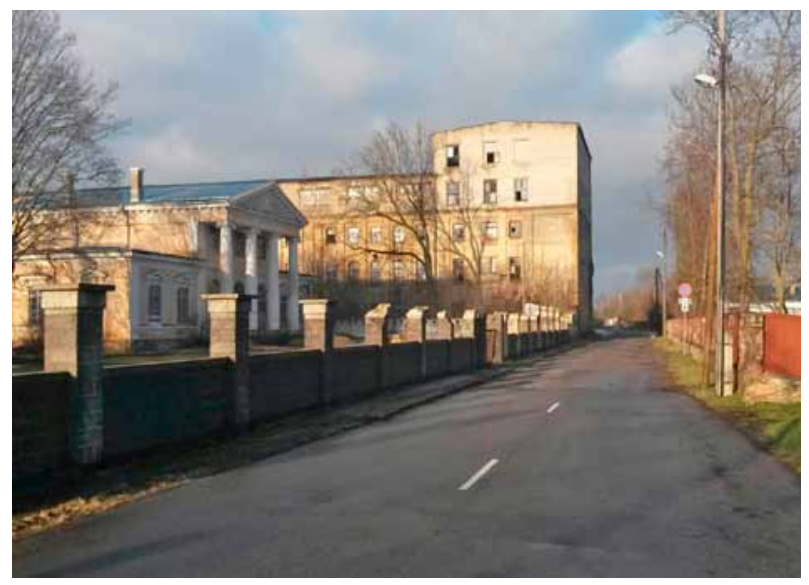

Fig. 10. The former flax spinning mill and Villa Medem Source: author's photo, 2015 


\section{Conclusions}

The research proves that the development of the road structure of the $17^{\text {th }}-19^{\text {th }}$ centuries has played an important role in the creation of the modern building "canvas" of Jelgava. The location of the industrial heritage in Jelgava has assembled essential urban development zones. Under the effect of the modern urban load, the historic industrial areas have changed their functional importance, but preserve the historical urban structure of Jelgava. The manor building of the $18^{\text {th }}-19^{\text {th }}$ centuries is transformed into clear high-rise or low-rise residential areas around Jelgava. Under the building load of the post-socialism period, the building of the cultural and historical heritage is $90 \%$ gone. But the historic sites of manors have provided an impetus to the development of a new building in these zones. These characteristics allow to easily define the network of the historical building around Jelgava.

With the intensification of the construction, in the extra-urban areas of Jelgava the green areas have receded over the past 50 years. In order to recover the term "Go Green", important solutions are needed for the new planning of the city development that could give the opportunity to link the cycle routes of the residential areas with the adjacent forest areas.

With the intensive development of the dense low-rise residential building of Jelgava, the areas of allotment gardens are disappearing. Wisely keeping them in an aesthetically high quality, the green zones should not be lost as they brightly complement the green "spine" of Jelgava. The "canvas" of allotment gardens marks the cultural and historical identity of the city.

The transformation of the cultural and historical building in the post-socialism period has given a new impetus to modern times. In other words, the awareness of the historical values, their study and the possibility of recovery in the urban environment of Jelgava is increasingly well understood.

\section{References}

Brinkis, J.; Buka, O. 2006. Pilsētu un lauku apdzīvoto vietu kompleksu arhitektoniski telpiskā plānošana. Rìga: RTU, 80, 139, $142,180,194$.

Briņķis,J; Buka,O. 2008. Reǵionālā attīstība un prognostika pilsētplānošanas kontekstā. Rīga, RTU, 27-109 p.

Grosmane, E. 2010. Senā Jelgava. Neputns, 24-71 p.

Jelgavas teritorijas plānojums. 1999-2010. Rīga: AGB, 9-127 p.

Schlau, O. 1995. Mitau im 19 Jahrhundert. Verlag Harro v. Hirschheydt, $455 \mathrm{p}$.

Tomašūns, A. 2015. Mana Jelgava. Jelgavas, 47-175 p.

Ziemeḷniece, A. 2010 The development of cultural historical space as one of the factors for the preservation of local landscape originality, Architecture and Urban Planning 4(10): 25-30.

Ziemeḷniece A. 2012. Conservation and development guidelines of the historical green structure of duke Jacobs canal, Architecture and Urban Planning 6: 51-55. https://doi.org/10.7250/aup.2012.008

İle, U. 2011. Development tendencies of landscape composition in urban residential areas of Latvia, Civil Engineering'11 $3^{\text {rd }}$ International Scientific Conference Proceedings, Volume 3: 193-201.

Treija, S.; Bratuškins, U.; Suvorovs E. 2010. The use of public open spaces in large scale housing estates in Riga, Architecture and Urban Planning 4: 44-50.

\section{AIJA ZIEMEL,NIECE}

Dr of Architecture, Professor, leading researcher. She graduated the program of study of Landscape Architecture of the Latvia University of Agriculture (from 1996). The direction of the scientific research - transformation processes of the cultural and historical landscape space and the opportunities of preservation of its regional identity. The research carried out - the urban environment of the region of Zemgale and the rural cultural landscape. Member of the Latvian Association of Architects, a member of the promotion boards of the Riga Technical University, the Latvia University of Agriculture. The expert of the Latvian Academy of Science in sector of Architecture and Landscape Architecture since 2008. Architect - project office Komunalproject (since 1980). Participation in architectural project competitions of state significance and winning the rights to elaborate technical projects and reconstruction - buildings schools and kindergardens, parks, hospital comlex, residental and administrative buildings etc. 